\title{
CSI i filtr eksplanacyjny: Dembski w ogniu krytyki
}

„Gort, Klaatu barada nikto!” Choć słowa te sprawiają wrażenie pozbawionych sensu, okazują się na wagę złota, kiedy aktorka Patricia Neal wypowiada je do ogromnego srebrnego robota o imieniu Gort. Scena ta rozgrywa się w klasyku science-fiction z 1951 roku pt. Dzień, w którym zatrzymała się Ziemia. ${ }^{1}$ Fabuła filmu skupia się na Klaatu (postaci granej przez brytyjskiego aktora Michaela Rennie), galaktycznym emisariuszu, który swoim latającym talerzem ląduje w pobliżu pomnika Waszyngtona. Chce on dać ludziom na Ziemi ultimatum: nauczycie się żyć w pokoju ze sobą albo zostaniecie unicestwieni jako zagrożenie dla innych planet. Klaatu towarzyszy Gort, robot wyposażony $\mathrm{w}$ przerażający laser, którego wiązki wylatują $\mathrm{z}$ otworu umieszczonego na jego głowie. Moc lasera jest imponująca. Gort użył go po tym, jak nerwowy żołnierz oddał salwę z czołgu i zranił Klaatu - czołg całkowicie wyparował. Po wyleczeniu w szpitalu Klaatu wymyka się pilnującym go funkcjonariuszom i wciela się w postać ,,pana

\footnotetext{
* Thomas Woodward, „CSI and Explanatory Filter: Dembski’s Trial by Fire”, rozdział w: Thomas Woodward, Darwin Strikes Back: Defending the Science of Intelligent Design, Baker Books, Grand Rapids, Michigan 2006, s. 135-152. Z języka angielskiego za zgodą Autora przełożył Dariusz Sagan. Recenzent: Robert Poczobut, Instytut Socjologii Uniwersytetu w Białymstoku.

${ }^{1}$ Film ten wyreżyserował Robert Wise (znany też z filmów The Sound of Music, Star Trek i wielu innych). Zwięzłe streszczenie fabuły tego obrazu zaczerpnąłem ze strony internetowej IMDb (która ogłasza się jako największa filmowa baza danych na świecie): www.imdb.com/title/tt0043456 (30.12.2005).
} 
Carpentera", lokatora domu, którego właścicielką jest młoda wdowa pani Benson (grana przez Patricię Neal).

Oszczędzę szczegółów fabuły i przeskoczę do sceny pościgu, w której Klaatu, przeczuwając, że zostanie w końcu schwytany, błaga panią Benson, żeby zapamiętała te dziwne słowa. Mówi jej, że jeśli coś mu się stanie, powinna pójść i wypowiedzieć te słowa do Gorta, który stoi unieruchomiony w pobliżu statku kosmicznego. Przerwę na chwilę, by zadać dwa pytania: (1) Skąd mamy wiedzieć, że to tajemnicze zdanie niesie prawdziwa informację i nie jest zwyktym betkotem? (2) Czy możemy dowiedzieć się, co ta wiadomość znaczy? Aby wykazać, że to zdanie nie jest bełkotem (bezsensownym pomieszaniem dźwięków), wystarczy tylko zademonstrować, że jest to potencjalnie sensowny ciąg słów w kontekście akcji filmu. Ale twierdzenie, że jest to zdanie ,sensowne”, natychmiast rodzi pytanie bardziej szczegółowe: co dokładnie te słowa znaczą? Możemy tylko zgadywać. Służą do aktywacji Gorta, najprawdopodobniej są zatem prostą komendą: „Ratuj Klaatu!" Nie można jednak wykluczyć, że w komputerowym mózgu Gorta znaczą one coś więcej: na przykład to, że „Klaatu każe włączyć sekwencję awaryjną XV-6", gdzie XV-6 to zestaw instrukcji zaprogramowanych $\mathrm{w}$ logicznej kolejności: (1) znalezienie Klaatu, (2) uporanie się z drzewami i innymi przeszkodami na drodze oraz (3) podjęcie wszelkich dalszych decyzji niezbędnych do udzielenia pomocy Klaatu. (Jeżeli oglądaliście film, wiecie, dlaczego o tym piszę). Kwestią zasadniczą jest reakcja Gorta; zostaje on uruchomiony za pomocą komendy i to jest najlepsze świadectwo, że to zdanie ma sens.

Czy analiza językowa pomoże określić jego sens? Pomijając wyraz „Gort”, możemy stwierdzić, że wiadomość ta zapisywana jest w postaci trzech słów składających się łącznie z siedemnastu liter, gdzie jedno słowo, Klaatu, ma znany sens. Sens pozostałych dwóch słów jest nieznany. Zdaje się, że utkwiliśmy w martwym punkcie. Możemy co najwyżej powiedzieć, że sens płynący z tych trzech słów wygląda na komendę aktywującą Gorta z powodu Klaatu. Ostatecznie nie musimy jednak znać dokładnego sensu zdania „Klaatu barada nikto”, aby wy- 
kryć obecność prawdziwej informacji - ciągu symboli, który niesie sens i ma takie kluczowe cechy, jak złożoność i specyfikacja. Ten ciąg symboli jest złożony - ukazuje wzorzec utworzony z licznych części składowych, które nie powtarzają się po prostu jak atomy sodu i chloru w krysztale soli. Ponadto jest on wyspecyfikowany - każdy symbol ciągu jest określony czy dobrany. W ciągu tym nie można dokonywać dowolnych podstawień symboli werbalnych (werbalnych mutacji), o ile sens ma zostać zachowany. To dlatego podczas sceny pościgu Klaatu powtarzał to zdanie pani Benson, dopóki dokładnie go nie zapamiętała z każdą samogłoską i spółgłoską na swoim miejscu. Sensowne zdanie wypowiedziane przez Klaatu charakteryzuje się zatem wyspecyfikowaną złożonością. Naprawdę niesie informację.

Co to wszystko ma wspólnego $\mathrm{z}$ darwinizmem i sporem o teorię inteligentnego projektu (ID - Intelligent Design)? Bardzo wiele. Teoretycy ID definiują bowiem wyspecyfikowana złożoność jako uniwersalną i niezawodną oznakę (kryterium) przyczyny inteligentnej, która pozostawiła po sobie ślad. Tam, gdzie znajdziecie wysoce wyspecyfikowane fragmenty złożonej informacji, natkniecie się na ślady inteligencji. Porównajmy film $\mathrm{z}$ biologią: składające się z trzech słów (siedemnastu liter) zdanie wypowiedziane przez Klaatu jest identyczne strukturalnie z systemem językowym DNA i białek. Jedno z mniej złożonych białek, cytochrom $\mathrm{C}$, składa się ze stu aminokwasów, czyli stu biochemicznych liter połączonych ze sobą, aby utworzyć długie białkowe słowo. Sekwencja aminokwasów jest jednak wynikiem translacji genu cytochromu $C$ - planu, określającego funkcję, który zawiera sekwencję DNA-RNA, liczącą nieco ponad trzysta liter genetycznych, ułożonych w sto kodonów (trzyliterowych słów zapisanych w DNA i RNA). Podobieństwo sekwencji DNA-RNA do zdań wypowiadanych przez ludzi (lub roboty) jest jeszcze większe, a to za sprawą obecności specjalnych słów na dwóch końcach sekwencji genowych - kodonu startu i kodonu stopu. Te specjalne słowa genetyczne 
pełnią rolę wielkiej litery i kropki, oznaczając początek i koniec sekwencji. $^{2}$

Wnioskowanie od informacji do inteligencji ma dodatkową podstawę w ważnym, choć często niedostrzeganym fakcie, który stanowi główną tezę empiryczną ID na temat informacji: wiemy, że komórki potrafia przetasowywać informację $i$ przestawiać geny $w$ genomie. Obserwacje i eksperymenty naukowe nie wykazaly jednak, że przyroda potrafi skladać wyspecyfikowana informacje genetyczna $w$ znaczacych ilościach. ${ }^{3}$ Podobnie jak zdanie „Klaatu barada nikto” jest wytworem inteligencji i zostało zakomunikowane inteligentnie zaprogramowane$\mathrm{mu}$, quasi-inteligentnemu systemowi (którym jest zaawansowany komputerowy mózg Gorta), tak - jak przekonują teoretycy ID - możemy wywnioskować, iż fragmenty wyspecyfikowanej, złożonej informacji w DNA, RNA lub białkach każdej rośliny czy zwierzęcia powstały na skutek projektu jakiejś inteligencji. Wniosek ten pozostanie niezachwiany dopóty, dopóki w przyszłości nie odkryjemy eksperymentalnie, że przyczyny naturalne w rzeczywistości potrafią tworzyć wyspecyfikowaną złożoność. Można nawet powiedzieć, że wnioskowanie o projekcie na podstawie wyspecyfikowanej złożoności jest głównym przedmiotem żarliwej debaty. Taka jest istota ID. Dodajmy, że tezy tej teorii są tak skrajnie odmienne od twierdzeń darwinizmu, jak tylko można sobie wyobrazić.

\footnotetext{
${ }^{2}$ Gwoli dokładności, kodony startu i stopu umieszczane są, oczywiście, na początku i końcu pozostałych stu kodonów, a więc formalnie rzecz ujmując cały ciąg liczy co najmniej 102 kodony.

${ }^{3}$ Temu zagadnieniu poświęcił swoje badania Ralph Seelke z University of Wisconsin. Wygląda na to, że dobór naturalny nie potrafi tworzyć nowych sensownych sekwencji DNA wymagających trzech jednoczesnych mutacji. Temat ten bardziej szczegółowo omówiłem w rozdziale dwunastym [książki Darwin Strikes Back].
} 


\section{Pomiar informacji w DNA}

Szukając wyjaśnienia powstania informacji biologicznej, Stephen Meyer i inni teoretycy ID skupili się na treści informacji zawartej $\mathrm{w}$ DNA, wyrażonej czteroliterowym alfabetem, utworzonym z czterech kwasów nukleinowych: A (adeniny), T (tyminy), C (cytozyny) i G (guaniny). (RNA składa się z podobnego zestawu liter z jedną różnicą: $\mathrm{T}$ jest zastąpione przez $\mathrm{U}$ - uracyl.) Za pomocą tych unikatowych zestawów liter, ułożonych w trzyliterowe słowa (wspomniane już kodony), komórka może przechowywać i kopiować tysiące złożonych, wyspecyfikowanych plików informacji genetycznej na swoim „twardym dysku" (w genomie). Wiemy, że minimalna ilość wyspecyfikowanej złożoności hipotetycznej bardzo prostej bakterii waha się w granicach 250 genów. (Jest to jednak nadzwyczaj skromna kalkulacja. Minimalny limit może być w istocie cztery lub więcej razy większy.) Powiedzmy, że każdy gen składa się średnio z 500 liter DNA. Iloczyn tych liczb wynosi 125000 liter, ułożonych precyzyjnie w cyfrowych plikach biologicznych. Ostatnie badania przeprowadzone przez Eugene'a Koonina wskazują jednak, że minimalna całkowita liczba liter genetycznych (zasad) w genomie najprostszej wyobrażalnej bakterii najprawdopodobniej mieści się w zakresie 318 000-562 000 liter. ${ }^{4}$

Porównajmy teraz minimalny limit Koonina z całą tą masą informacji zawartych w tekście niniejszej książki. Pisząc książkę, używałem funkcji liczenia słów, aby sprawdzić, jak bardzo rozrósł się każdy z rozdziałów. Narzuciłem sobie limit około 6000 słów na rozdział, czyli średnio nieco ponad 30000 liter. Przyjmując te dane za podstawę, możemy ustalić, że typowa genetyczna biblioteka Koonina dla najprostszej bakterii zawierałaby co najmniej tyle wyspecyfikowanych

\footnotetext{
${ }^{4}$ Por. słynny artykuł przeglądowy Stephena Meyera, „The Origin of Biological Information and the Higher Taxonomic Categories". Artykuł dostępny jest w Internecie pod adresem: http://www.discovery.org/scripts/viewDB/index.php?command=view\&id=2177 (21.01.2008). Meyer odnosi się do artykułu Eugene'a Koonina, „How Many Genes Can Make a Cell?”, Annual Review of Genomics and Human Genetics 2000, vol. 1, s. 99-116.
} 
liter, co dziesięć dłuższych rozdziałów niniejszej książki razem wziętych - innymi słowy, byłaby ona tak długa, jak niniejsza książka [licząca 222 strony] lub dłuższa! Odnoszę wrażenie, że nawet najlepiej wykształceni Amerykanie nie wiedzą, iż genomy nawet możliwie najprymitywniejszych form życia muszą zawierać tak zdumiewającą ilość złożonego, wyspecyfikowanego DNA. Całkowita liczba informacji u zwierząt wyższych, mieszczących w swoich jądrach komórkowych 20000 genów, byłaby zatem pięćdziesiąt razy (do stu razy) większa równa być może informacji zawartej w stu lub ponad stu książkach. ${ }^{5}$ Obok Michaela Behe’ego koncepcji nieredukowalnej złożoności, ta brutalna rzeczywistość informacyjna - olbrzymie bazy danych materiału informacyjnego w DNA, RNA i białkach - stanowi drugą główną siłę napędową teorii ID. Tego typu informacji (zawartej w książkach napisanych przez ludzi lub w genomach DNA) nadano specjalną nazwę: CSI.

\section{CSI i filtr eksplanacyjny}

Nie należy mylić tej CSI z popularnym serialem telewizyjnym o tym samym tytule. W nazewnictwie teorii inteligentnego projektu CSI (Complex Specified Information) znaczy „Złożona Wyspecyfikowana Informacja”. Wzorce informacyjne często nazywane są też „wyspecyfikowaną złożonością". Te dwa terminy praktycznie odnoszą się do tego samego. Koncepcję CSI rozwinęli głównie William Dembski i Stephen Meyer w latach 1992-1996.

Jak na podstawie CSI (czy wyspecyfikowanej złożoności) można w sposób logicznie poprawny - wyprowadzić wniosek o istnieniu przyczyny inteligentnej, która odpowiada za wytworzenie CSI?

\footnotetext{
${ }^{5}$ Oczywiście, nie biorę pod uwagę występujących u wyższych eukariontów regionów niekodujących, które niegdyś nazywano „śmieciowym DNA”. Ostatnie badania sugerują, że ów „śmieciowy DNA” wcale nie jest śmieciowy i może pełnić wiele funkcji, o których wcześniej nie mieliśmy pojęcia.
} 
Dembski wskazał jedną kluczową drogę: połączył CSI z inną ważną ideą - „filtrem eksplanacyjnym”. Zgodnie z koncepcją filtra, której oponenci ID nie szczędzili uwagi i krytyki, każde zdarzenie lub obiekt w przyrodzie można przeanalizować za pomocą serii statystycznych czy probabilistycznych testów w celu sprawdzenia, czy prawdopodobną ich przyczyną było prawo przyrody, czy przypadek. (Statystyka i teoria prawdopodobieństwa to specjalność Dembskiego; jeden ze swoich dwóch doktoratów uzyskał $\mathrm{w}$ dziedzinie matematyki.) Jeżeli odrzucimy hipotezę prawa i przypadku, ostatnim testem (czyli „testem specyfikacji”) jest sprawdzenie, czy dane zdarzenie lub obiekt można przypisać projektowi. Koncepcja filtra eksplanacyjnego jest przedmiotem intensywniejszego sporu niż CSI. Na temat Dembskiego i jego filtra przelano więcej atramentu, w druku czy - metaforycznie - w Internecie, niż na jakikolwiek inny temat związany z ID (z wyjątkiem Michaela Behe'ego i jego koncepcji). Celem czterech największych „bomb penetrujących” wymierzonych w ID w 2004 roku - książek, o których pisałem w rozdziale czwartym [książki Darwin Strikes Back - Darwin kontratakuje] ${ }^{* *}$ - była zarówno praca Dembskiego, jak i Behe'ego. Autorzy wszystkich czterech książek szczegółowo krytykowali argumentację Dembskiego, ale rekord świata należy do Marka Perakha, który w swojej pracy Unintelligent Design [Nieinteligentny projekt] cały pierwszy rozdział, liczący aż dziewięćdziesiąt dwie stro$n y$, poświęcił krytyce koncepcji autorstwa tego właśnie matematyka $\mathrm{z}$ ruchu ID. (Jest to prawie jedna czwarta liczącej 415 stron książki, podzielonej na 14 rozdziałów, w których Perakh mierzy się z czternastoma wybranymi problemami.)

Każdego pisarza, pragnącego streścić tę wielką debatę, kusi, aby po prostu zacytować niektóre fragmenty z literatury krytycznej wobec

\footnotetext{
** (Przyp. thum.) - Niall Shanks, God, the Devil, and Darwin: A Critique of Intelligent Design Theory, Oxford University Press, Oxford, England 2004; Barbara ForRest and Paul Gross, Creationism's Trojan Horse: The Wedge of Intelligent Design, Oxford University Press, Oxford, England 2004; Mark Perakh, Unintelligent Design, Prometheus Books, Amherst, NY. 2004; Matt Young and Taner Edis (eds.), Why Intelligent Design Fails: A Scientific Critique of the New Creationism, Rutgers University Press, New Brunswick, NJ. 2004.
} 
ID, następnie skopiować długie fragmenty z książki Dembskiego, The Design Revolution [Rewolucja projektu], i na tym skończyć. Książka ta jest niezwykle ważną pozycją na temat publicznej debaty nad ID. Znajdują się w niej odpowiedzi na ponad czterdzieści pytań - wiele z tych pytań to wrogie torpedy, mające posłać ID na dno. Postarałem się nie przesadzić z cytatami z The Design Revolution, ale zachęcam czytelników do nabycia egzemplarza tej książki i przeczytania jej równocześnie $\mathrm{z}$ niniejszym rozdziałem. Ułatwi to zrozumienie zdecydowanej reakcji zwolenników ID na omawianą tutaj krytykę. ${ }^{6}$

W niniejszym rozdziale skupię się na sporze o CSI, a zwłaszcza o filtr eksplanacyjny. Najpierw krótko przyjrzę się kontekstowi, w którym koncepcja filtra powstała - jak się rozwijała i jak funkcjonuje w swojej najnowszej postaci. Następnie przedstawię dwie najsilniejsze krytyki filtra i argumentów Dembskiego wziętych ogółem. ${ }^{7}$ Obok krytyki omówię także odpowiedzi Dembskiego, zaś w zakończeniu niniejszego rozdziału zapoznam was z jego najsilniejszą, jak dotychczas, krytyką paradygmatu darwinowskiego, którą przedstawił w The Design Revolution.

\section{Historia filtra}

Za każdą wielką ideą naukową lub odkryciem kryje się fascynująca historia ich twórcy. Tak właśnie jest w przypadku Williama Dembskiego i jego filtra eksplanacyjnego. W rozdziale dziewiątym książki Doubts about Darwin [Wątpliwości na temat darwinizmu] pisałem przeważnie o historii Dembskiego - jego wykształceniu akademickim,

\footnotetext{
${ }^{6}$ William A. Dembsкi, The Design Revolution: Answering the Toughest Questions about Intelligent Design, InterVarsity Press, Downers Grove, Ill. 2004.

${ }^{7}$ Gdybym miał uwzględnić każdy atak na Dembskiego, mógłbym napisać dosłownie ponad sto stron i zanudzić was przy tym na śmierć. Podsumowanie innych ataków na Dembskiego i filtr oraz replikę na nie można znaleźć na stronie Discovery.org, przeznaczonej dla książki Darwin Strikes Back - dokładnie chodzi o listę „Attacks on Dembski”.
} 
którego owocem są dwa doktoraty; o opublikowaniu przez Cambridge University Press jego głośnej książki The Design Inference [Wnioskowanie o projekcie], która przeszła przez fachowy proces recenzji; o istocie filtra eksplanacyjnego oraz o trudnej karierze Dembskiego jako profesora Baylor University. ${ }^{8}$ Tutaj pominę te szczegóły. Przybliżę natomiast koncepcję filtra eksplanacyjnego. Powrócę we wspomnieniach do ożywionej konwersacji, jaką odbyłem z Dembskim po tym, jak w sierpniu 1993 roku wyszedł z budynku lotniska w Seattle. Byliśmy już wtedy przyjaciółmi. Poznaliśmy się na pewnym wykładzie filozoficznym w Princeton University w 1990 roku i od tamtej pory uczestniczyliśmy razem $\mathrm{w}$ różnych sympozjach akademickich. ${ }^{9}$ Ucięliśmy sobie pogawędkę, gdy jechaliśmy wypożyczonym samochodem na spotkanie Ad Hoc Origins Committee - forum ludzi sceptycznie nastawionych względem biologii darwinowskiej, będącego zapowiedzią Ruchu Inteligentnego Projektu. Wątpię, by pamiętał on tę rozmowę, ale dla mnie jest ona niezapomniana. Najpierw rozmawialiśmy o zwykłych sprawach, a potem Bill wspomniał mimochodem o kiełkującej w jego umyśle koncepcji filtra eksplanacyjnego. Nie miałem zielonego pojęcia, na czym koncepcja ta polega, więc poprosiłem go, aby mi ją wythumaczył.

Prowadziłem i oczywiście nie mogłem zrobić notatek, ale wielokrotnie odtwarzałem tę rozmowę w swojej głowie i mam wrażenie, że zapamiętałem ją praktycznie w całości. Dembski wyjaśnił, że jeśli ktoś chciałby się dowiedzieć, przy zachowaniu ścisłości logicznej i matematycznej, czy zjawisko $\mathrm{X}$ - jakiś podejrzany obiekt lub zdarzenie - jest rezultatem inteligentnego projektu, to musi przepuścić je przez trzy filtry. Po pierwsze, należy zapytać, czy zjawisko $\mathrm{X}$ jest wysoce prawdopodobne, czyli takie, że z łatwością mogło je spowodować działanie jakiegoś jednego lub większej ilości praw przyrody. Je-

\footnotetext{
${ }^{8}$ Por. Thomas Woodward, Doubts about Darwin: A History of Intelligent Design, Baker Books, Grand Rapids, Michigan 2003, s. 171-182.

${ }^{9}$ Dembski przyszedł na wykład filozofa Alvina Plantingi, wygłoszony w Whig-Clio Hall w Princeton University w 1990 roku. Wówczas Dembski odbywał na tej uczelni staż podoktorski.
} 
żeli X faktycznie jest wysoce prawdopodobne (jak w przypadku wielokrotnie upuszczanej piłki, która zawsze opada na podłogę z prawdopodobieństwem bliskim 100 procent), to można uznać je za w pełni wyjaśnione za pomocą prawa lub konieczności (w przypadku piłki jest to grawitacja). Jeżeli jednak X nie uzyskało wyjaśnienia, ponieważ nie jest wysoce prawdopodobne, to należy przejść do kolejnego filtra. Pytamy się teraz, czy X wykazuje średnie lub umiarkowanie małe prawdopodobieństwo - $\mathrm{w}$ tym wypadku bez problemu można wyjaśnić $\mathrm{X}$ przez odwołanie się do przypadku. Przykładem może być tutaj podrzucanie monety; wyrzucenie orła da się wyjaśnić przypadkiem, bowiem uśrednione prawdopodobieństwo tego zdarzenia wynosi jedną drugą lub 50 procent. (Później ten stopień przypadku nazwano ,prawdopodobieństwem pośrednim".)

Drugi filtr, czyli filtr przypadku, może objąć nawet zdarzenia o umiarkowanie małym prawdopodobieństwie. Aby to zilustrować, przeskoczę $\mathrm{w}$ myślach od wypożyczonego samochodu do nocy poświęconych grze w pokera (gdzie stawką jest ogromny słój centów), które stanowią ulubioną rozrywkę Rona i Janet oraz ich przyjaciół, Jasona i Lori. Ron zazwyczaj wygrywa. Wyobraźmy sobie zatem, że Ron otrzymał (dosłownie) doskonałe rozdanie - królewskiego pokera pik. Prawdopodobieństwo takiego rozdania wynosi 1 na 2598 960, co jest bardzo mało prawdopodobnym zdarzeniem, ale nie aż tak, by nie można było uznać, iż komuś takie rozdanie się poszczęściło. Jeśli w USA w tym roku wykonano 2600000 rozdań pokerowych (a faktycznie mogło być ich znacznie więcej), to jest bardzo prawdopodobne, że ktoś otrzyma gdzieś to rzadkie rozdanie, a to dlatego, że jest tak wiele prób. (Liczba prób uzyskania nieprawdopodobnego zdarzenia odgrywa szczególną rolę w rozumowaniu Dembskiego. Nazywana jest ,zasobem probabilistycznym” typu „replikacyjnego" - i tyle szczegółów technicznych, jak sądzę, powinno nam wystarczyć. ${ }^{10}$ )

Jeśli za pomocą filtra przeanalizujemy ten radosny triumf Rona, zdarzenie to przejdzie przez pierwszy filtr (nie jest ono wysoce praw-

\footnotetext{
${ }^{10}$ Por. Dembski, The Design Revolution..., s. 82-83.
} 
dopodobne lub prawopodobne [lawlike]), ale zatrzyma się na filtrze drugim, ponieważ jego prawdopodobieństwo wynosi tylko jeden na $2,5 \times 10^{6}-$ a więc $\mathrm{w}$ grę wchodzi tu umiarkowanie małe prawdopodobieństwo. Innymi słowy, doskonałe rozdanie Rona da się łatwo wyjaśnić przypadkiem. O ile wiemy, nikt nie oszukiwał; nie było to zdarzenie zaprojektowane.

Wyobraźmy sobie teraz (zaiste niezwykły) scenariusz nocnego maratonu pokerowego, podczas którego było dwadzieścia pięć rozdań i ku niezmiernemu zaskoczeniu wszystkich graczy (co zresztą wzbudziło ich uzasadnione podejrzenia) Ron otrzymał drugiego królewskiego pokera pik, a potem trzeciego, czwartego i tak dalej w każdym kolejnym rozdaniu tej nocy, pomimo usilnych prób gruntownego przetasowania kart pomiędzy rozdaniami. Prawdopodobieństwo całego tego zmyślonego zdarzenia jest znikomo małe - dużo poniżej jednej szansy na $10^{150}$ ! Jak przeanalizujemy ten hipotetyczny wynik za pomocą filtra?

Powróćmy do rozmowy z Dembskim, jaką odbyliśmy jadąc samochodem przez Seattle. Wyjaśnił on, że jeżeli zjawisko X nie zatrzyma się na pierwszym filtrze (wysokie prawdopodobieństwo) lub drugim (średnie do umiarkowanie małego prawdopodobieństwa), to $\mathrm{z}$ definicji jest to ,zdarzenie o bardzo małym prawdopodobieństwie” i przechodzi do trzeciego i ostatniego filtra, w którym sprawdzana jest możliwość, że zostało ono zaprojektowane. Zanim jednak omówimy ten filtr, musimy się zatrzymać i zapytać: jak małe prawdopodobieństwo jest bardzo małe? Innymi słowy, przy jak małym prawdopodobieństwie można przejść od drugiego filtra do ostatniego? Osobiście podejrzewałbym ,inteligentny projekt” (przebiegłą ingerencję) w grze pokerowej, gdyby królewski poker pojawił się w dwóch rozdaniach pod rząd (czego prawdopodobieństwo równa się 1 na $6 \times 10^{12}$ ), a co dopiero $\mathrm{w}$ dwudziestu pięciu kolejnych rozdaniach. Biorąc jednak pod uwagę tak wielki Wszechświat, w którym oddziałuje ze sobą tak duża ilość materii i który istnieje już tak długo, Dembski postanowił być maksymalnie powściągliwy. Ustanowił on standard dla bardzo małego prawdo- 
podobieństwa w odniesieniu do zdumiewająco rzadkich zdarzeń: rzadszych od jednej szansy na $10^{150}$ ! Liczba ta uzyskała nazwę ,wszechświatowa granica prawdopodobieństwa" filtra eksplanacyjnego. (Dwudziestowieczny matematyk francuski Emil Borel ustalił swoją „wszechświatową granicę prawdopodobieństwa” na $10^{-50}$; inni zasugerowali nieco większą granicę niż Borel. ${ }^{11}$ ) Potrzeba dwudziestu pięciu kolejnych doskonałych rozdań pokerowych, aby dotrzeć do ustalonej przez Dembskiego wszechświatowej granicy prawdopodobieństwa, ale wystarczyłoby ich osiem, aby osiągnąc granicę wyznaczoną przez Borela. Jak napomknąłem wcześniej, dla Woodwarda „wszechświatową granicę prawdopodobieństwa w pokerze" stanowiłyby dwa lub co najwyżej trzy takie rozdania!

Z formalnego punktu widzenia, każde złożone zdarzenie lub obiekt ma nadzwyczaj małe prawdopodobieństwo, a skoro tak, to jak uchronimy się przed uznaniem za „zaprojektowane” jakiegoś przypadkowego jedynie i nic nieznaczącego skutku, takiego jak wynik tysiąckrotnego podrzucenia monety? Wzorzec takich rzutów monetą miałby prawdopodobieństwo (jeden na $10^{300}$ ) ${ }^{12}$ przekraczające wyznaczoną przez Dembskiego granicę nawet skrajnie małego prawdopodobieństwa, ale to oczywiste, że nie jest wynikiem działania inteligencji. Odpowiedź znajdujemy $\mathrm{w}$ trzecim i ostatnim filtrze, o którym wspomniałem już wcześniej. Gdy w wypożyczonym samochodzie Bill przedstawiał swoje trójfiltrowe wyjaśnienie, powiedział, że jeżeli X nie jest zdarzeniem wysoce albo średnio lub umiarkowanie mało prawdopodobnym, to przechodzi do trzeciego filtra, który sprawdza, czy $X$ pasuje do pewnego niezależnego idealnego czy wyspecyfikowanego wzorca. Jest to tzw. ,filtr specyfikacji”.

Być może łatwiej będzie to zrozumieć na przykładzie, ale muszę zastąpić pokera „subtelnymi wiadomościami kuchennymi”. Litery roz-

\footnotetext{
${ }^{11}$ Por. Dembski, The Design Revolution..., s. 84-86. Dembski wskazuje, że wielkość zaproponowanych (w publikacjach) wszechświatowych granic prawdopodobieństwa zawierała się w zakresie od $10^{-94}$ do $10^{-120}$. Granica Dembskiego jest najbardziej łagodną w literaturze.

${ }^{12}$ Por. Dembsкi, The Design Revolution..., s. 76.
} 
sypane z przewróconego pudełka płatków zbożowych firmy Alpha Bits na naszym stoliku śniadaniowym utworzą ciekawe wzorce, lecz na pewno nie taki oto wzorzec: „TOM, WYNIEŚ ŚMIECI”. Naturalnie, zinterpretowałbym ten ciąg piętnastu liter jako niezwykle twórcze przypomnienie mojej żony i nie zignorowałbym go myśląc, że jest to rezultat niecodziennego, losowego zbiegu okoliczności. To właśnie tego typu wyspecyfikowany wzorzec - utworzony z płatków zbożowych, wielokrotnych pokerów królewskich czy niezbędnych do życia sekwencji DNA - sprawia, że filtr eksplanacyjny ma tak wielką siłę. Jeżeli zatem coś jest zarówno „bardzo nieprawdopodobne” (przechodząc przez pierwsze dwa filtry), jak i „wyspecyfikowane” (przechodząc przez ostatni filtr), to możemy w prosty i bezpośredni sposób uznać, że zaprojektowała lub ukształtowała to jakaś inteligencja. Nie był to przypadek czy zwykłe głupie szczęście.

Podsumowując, Dembski i Meyer, podobnie jak inni teoretycy ID, czują, że nauka jest teraz w posiadaniu opartego na zasadach i skutecznego narzędzia - filtra eksplanacyjnego - dzięki któremu można wykryć działanie przyczyn inteligentnych, tworzących projekty układów fizycznych. Gdy tylko jakaś zbitka sekwencji genowych lub niewielki zespół sekwencji białkowych (aminokwasowych) zostaną poddane sprawdzeniu przez filtr eksplanacyjny, zawsze okazuje się, że są wytworem projektu, a nie prawa czy przypadku ( $\mathrm{tj}$. działania przyczyn naturalnych). W książce No Free Lunch [Nic za darmo] (2002) Dembski określił ilościowo strukturę wici bakteryjnej w taki sposób, że można ją było przeanalizować za pomocą filtra. Wynik nie był niespodzianką. Za sprawą precyzyjnego wyspecyfikowania czterdziestu białek składowych wici, dzięki którym pełni ona swoją funkcję, jak również z powodu skrajnie małego ogólnego prawdopodobieństwa powstania tej struktury (wynoszącego $10^{-1170}$, co dalece przekracza wyznaczoną przez Dembskiego granicę prawdopodobieństwa), filtr z łatwością i zdecydowanie przypisał ją projektowi. Prawdopodobieństwo, że wić powstała na skutek losowej selekcji biologicznych liter, 
przez co utworzyło się czterdzieści białek, jest równe prawdopodobieństwu otrzymania 190 pokerów królewskich pod rząd! ${ }^{13}$

W ciągu minionych kilkunastu lat filtr eksplanacyjny uległ drobnym modyfikacjom, lecz podstawowa idea pozostała taka sama; zmieniła się lub została skorygowana tylko terminologia. W swojej najaktualniejszej postaci, przedstawionej w The Design Revolution, ${ }^{14}$ istota filtra pozostała bez zmian. W jego skład wchodzą po prostu trzy „węzły decyzyjne”:

1. Przygodność - jeśli zjawisko X nie jest przygodne, czyli jeżeli $\mathrm{X}$ nie jest „niekonieczne”, to jest prawopodobne (lawlike) i zostaje w pełni wyjaśnione w tym węźle. Jeśli jest przygodne lub niekonieczne, przechodzi do węzła następnego.

2. Złożoność - jeśli zjawisko $X$ nie jest bardzo złożone, czyli jeżeli prawdopodobieństwo jego zajścia jest większe niż jedna szansa na $10^{150}$, to zatrzymuje się w drugim węźle i można je przypisać przypadkowi. Jeżeli jego prawdopodobieństwo jest bardzo małe, przekraczające tę granicę prawdopodobieństwa, to przechodzi do następnego węzła.

3. Specyfikacja - jeśli zjawisko X, uznane już za wysoce złożone i niewiarygodnie nieprawdopodobne, okaże się ponadto wyspecyfikowane, pasujące do niezależnego wzorca, to przypisuje się je projektowi. Jeżeli nie jest wyspecyfikowane, to również tym razem można wyjaśnić je działaniem przypadku.

\footnotetext{
${ }^{13}$ Por. omówienie tego zastosowania filtra do wici w: Kenneth R. Miller, „The Flagellum Unspun: The Collapse of «Irreducible Complexity»", w: Michael Ruse and William A. Dembsk (eds.), Debating Design: From Darwin to DNA, Cambridge University Press, Cambridge 2004, s. 81-97.

${ }^{14}$ Dembski, The Design Revolution..., s. 88.
} 
Najnowsza postać filtra nie różni się zbytnio od wersji, o której usłyszałem w 1993 roku w trakcie przejażdżki wypożyczonym samochodem. Niektórzy krytycy darwinowscy zrobili z wprowadzonych przez Dembskiego zmian w filtrze wielką sensację, wskazując, że nie potrafi się on zdecydować lub stale koryguje błędy. Zarzut ten jest jednak nietrafny. Każda dobra idea naukowa przechodzi nieustanny proces wprowadzania poprawek i ulepszeń.

Retoryczne piękno filtra ujawnia się na wielu płaszczyznach. Po pierwsze, jest to metoda powściągliwa - wniosek o projekcie nie jest wyciągany zbyt pochopnie. Po drugie, jest ścisła - do wniosku o projekcie prowadzi metodyczna statystyczna analiza prawdopodobieństw. Po trzecie, ukazuje również neutralną pod względem religijnym naturę teorii inteligentnego projektu, w tym sensie, że wskazuje na ,inteligencję" w ogóle, a nie na jakiś czynnik lub czynniki o ustalonej tożsamości. I wreszcie po czwarte, jest to dobrze potwierdzona metoda wyjściowa, gdyż została zweryfikowana empirycznie czy indukcyjnie. Według Dembskiego nigdy nie prowadzi ona do fałszywych rezultatów:

\begin{abstract}
Uzasadnieniem tego twierdzenia [o niezawodności tego kryterium] jest prosta generalizacja: zawsze tam, gdzie obecna jest wyspecyfikowana złożoność i gdy znana jest związana z nią historia przyczynowa (tj. kiedy nie tylko mamy do czynienia $\mathrm{z}$ poszlakami, ale mamy coś $\mathrm{w}$ rodzaju kamery wideo i domniemanego projektanta można przyłapać na gorącym uczynku), tam obecny jest też projekt [...]. To śmiała i fundamentalna teza, a więc warto ją powtórzyć: Tam, gdzie możliwe jest bezpośrednie potwierdzenie empiryczne, wyspecyfikowanej złożoności zawsze towarzyszy projekt. ${ }^{15}$
\end{abstract}

Jeżeli zatem praca Jonathana Wellsa, który gruntownie krytykuje „dowody” na przyrodniczą makroewolucję, jest przykładem negatywnego wkładu ID, związanego z krytyką bazy empirycznej darwinizmu,

\footnotetext{
${ }^{15}$ Dembski, The Design Revolution..., s. 95-96.
} 
to pozytywnym wkładem ID na rzecz empirycznego potwierdzenia hipotezy projektu jest koncepcja CSI oraz filtra eksplanacyjnego.

\section{Kontratak darwinistów na Dembskiego i jego filtr}

To normalne, że każda nowa i kontrowersyjna idea naukowa, taka jak filtr eksplanacyjny, jest poddawana przez jej oponentów możliwie najsurowszej ocenie i dokładnej analizie. Tak stało się również w tym wypadku. Należy przyznać, że ostra krytyka z pewnością jest niezbędną (a może i bolesną) częścią wcielania koncepcji ID do nauki głównego nurtu. Wspomnijmy przy okazji, że związana z filtrem koncepcja CSI (wyspecyfikowanej złożoności), do której tak często odwołują się teoretycy projektu, nie spotkała się z równie dużą krytyką. Pojawiają się głosy krytyczne, ale są one znacznie cichsze. Być może ma to związek z faktem, że CSI pełni rolę bardziej podstawowej, opisowej koncepcji, stosowanej nawet przez wybitnych naukowców spoza ID, ${ }^{16}$ i sama w sobie nie prowadzi ewidentnie do wniosku o projekcie.

Stanowcza krytyka nowych koncepcji naukowych i metodologii to zjawisko normalne i pożyteczne. Mniej powszechne (i bardziej niestosowne) są natomiast ataki oponentów nowej idei naukowej na osoby, które tę ideę opracowują. Właśnie z takim atakiem spotkał się Dembski. Zapewne z powodu zagrożenia, związanego z jego koncepcjami, darwiniści przyjęli brzydką strategię personalnych ataków na Dembskiego, w których znalazło się miejsce dla drwin i pogardy. Krytycy darwinowscy często zarzucają Dembskiemu (na przykład) wyjątkową pewność siebie, graniczącą wręcz z arogancją, jeśli chodzi o znaczenie

\footnotetext{
${ }^{16}$ W The Design Revolution..., rozdz. 10, s. 81, Dembski wskazuje na Lesliego Orgela jako pierwszego naukowca, który posłużył się tym terminem w swojej książce The Origins of Life: Molecules and Natural Selection, Wiley, New York 1973. Przytacza także słowa Paula Daviesa, który użył tego wyrażenia w książce The Fifth Miracle: The Search for the Origin and Meaning of Life, Simon and Schuster, New York 1999, o której pisałem w poprzednim rozdziale [książki Darwin Strikes Back]
} 
jego własnych idei. ${ }^{17}$ Wielokrotnie stawiają zarzut, że Dembski (aż do przesady) posługuje się nużącymi „formalizmami matematycznymi” lub „matematyzmem jako środkiem ozdobnym” ${ }^{18}$ po to tylko, aby swoją naukową erudycją sprawić większe wrażenie na laikach. Uważam, że krytyka ta jest absurdalna, niesprawiedliwa i zupełnie mijająca się z celem. Wskazuje ona co najwyżej na poziom desperacji darwinistów, którzy muszą uderzać w Dembskiego wszystkim, co mają pod ręką. W każdym razie moim obecnym celem jest przyjrzenie się głosom krytycznym z całkowitym pominięciem wzajemnego obrzucania się błotem i skupienie się na zarzutach rzeczowych.

\section{Problem splotu przyczyn}

Według jednego z najczęstszych zarzutów filtr eksplanacyjny analizuje tylko jedną przyczynę naraz, a przecież w niemal każdym możliwym do wyobrażenia przypadku jednocześnie działa więcej przyczyn niż jedna. Perakh formułuje ten zarzut następująco: „Proponowane przez Dembskiego kategoryczne rozgraniczenie prawa, przypadku i projektu jako trzech niezależnych przyczyn również nie wydaje się realistyczne, ignoruje bowiem liczne sytuacje, kiedy w grę wchodzą dwie lub trzy przyczyny równocześnie". ${ }^{19}$ Zarzut ten powtarza kilku innych krytyków, zwłaszcza Michael Ruse. ${ }^{20}$ Chodzi o to, że gdy np.

\footnotetext{
${ }^{17}$ Strategia ataków personalnych jest typowa dla ataków na Dembskiego. Por. ForRest and Gross, Creationism's Trojan Horse..., s. 118: „Wynika z tego, oczywiście, że to on w pojedynkę rozwiązał odwieczną zagadke logiki, matematyki, nauk przyrodniczych, metafizyki i filozofii moralnej - zagadkę, której nie potrafiły one rozgryźć aż do chwili obecnej: odkrycie prawdy o celowym zaprojektowaniu życia przez niepojmowalnie inteligentny, pozaprzyrodniczy byt”. Po zaprezentowaniu głównych argumentów Dembskiego autorzy stwierdzają, bezpodstawnie i nie okazując zbytniej wyrozumiałości, że „Nie tak wypowiada się skromny młody uczony".

${ }^{18}$ Cytaty te pochodzą z: Forrest and Gross, Creationism's Trojan Horse..., s. 123; oraz Perakh, Unintelligent Design..., s. 26-28.

${ }^{19}$ Perakh, Unintelligent Design..., s. 104.

${ }^{20}$ Por. omówienie Dembskiego w: The Design Revolution..., s. 93.
} 
jakieś zdarzenie jest rezultatem przypadku (jak wynik jednego rzutu monetą lub jeden poker królewski Rona), to tym samym jeszcze nie narusza ono prawidłowości przyrody, takich jak fizyczna substancja monet i kart, prawo grawitacji, które kontroluje ruch monet i kart, kiedy przecinają one powietrze i tak dalej. To samo dotyczy sytuacji, kiedy jakiś obiekt jest wytworem projektu; w pewnym stopniu działają tu również prawo i przypadek. Być może rozjaśni nam to cytat z Perakha:

Rozważmy podany przez Dembskiego przykład zawodów łuczniczych. Jeżeli lucznik wystrzeli strzałę i trafi do celu, to - zgodnie z Dembskim - należy uznać to zdarzenie za wyspecyfikowane i kategorycznie przypisać je projektowi. W schemacie Dembskiego projekt wyklucza i przypadek, i prawo. Czy jednak rzeczywiście możemy wykluczyć prawo jako przyczynę poprzedzającą to zdarzenie? Uważam, że sukces łucznika nie był rezultatem wyłącznie projektu, lecz splotu projektu i prawa. W rzeczywistości zdolności łucznika objawiają się tylko w nadaniu strzale pewnej prędkości w momencie wystrzelenia z łuku. Owa prędkość jest rezultatem projektu. Jednakże, jak tylko strzała wylatuje z łuku, jej dalszym lotem rządzą prawa mechaniki. To wyspecyfikowane zdarzenie - trafienie w dziesiątkę - było wynikiem połączenia projektu i prawa. Strzała nie trafiłaby do celu, gdyby brakowało jednej z tych dwóch przyczyn poprzedzających. W tym wypadku projekt działa w połączeniu z prawem i bez prawa byłby niemożliwy. ${ }^{21}$

Na pierwszy rzut oka wydaje się, że Perakh i inni krytycy odkryli fundamentalną słabość filtra. Ale czy rzeczywiście? Kiedy po raz pierwszy zapoznałem się $\mathrm{z}$ postawionym przez Perakha zarzutem „splotu przyczyn”, przyszła mi do głowy myśl, że w ogóle nie jest związany z tematem. Przypomnijmy sobie przykład przewróconego pudełka słodkich płatków w kształcie liter, które utworzyły na stole przypomnienie od mojej żony. Żadna rozsądna, obeznana w nauce osoba nawet przez moment nie zaprzeczyłaby, że swoim wewnętrznym składem, ruchami przy wysypywaniu się z pudełka i podczas

\footnotetext{
${ }^{21}$ PeraKh, Unintelligent Design..., s. 32.
} 
układania w ścisłym porządku przez kochającą żonę litery te podlegały prawom fizyki i chemii. Funkcjonowanie wszystkich normalnych praw fizycznych jest zatem czymś w rodzaju kontekstu - istniejącym już podłożem całego badanego systemu. Nie zaobserwowałem struktury chemicznej cukrów i węglowodanów w płatkach i nie wykrzyknąłem: „Otóż to! To rządzące cząsteczkami pokarmowymi prawa chemiczne w połączeniu z przypadkiem wytworzyły wiadomość!” Taki wniosek byłby absurdem. Prawa fizyki i chemii faktycznie współdziałały z projektem $\mathrm{w}$ utworzeniu wiadomości z płatków, ale same prawa nie są zadowalającym wyjaśnieniem; ich rola jest względnie trywialna i wyjaśnienie wytacznie za ich pomocą nie jest w tym wypadku ani wystarczające, ani przekonujące.

Podobnie chemik i fizyk mogą połączyć siły i prowadzić szczegółowe badania nad działaniem szyldu neonowego. Za pomocą praw przyrody wyczerpująco mogą oni wyjaśnić tylko to, jak funkcjonuje obwód elektryczny i dlaczego neon jarzy się na czerwono. Jednakże nie wyjaśnią w ten sposób pochodzenia kształtów „Drink Coke”, utworzonych przez wypełnione neonem rurki. Prawo fizyczne (lub przypadek) nigdy nie wyjaśni adekwatnie wiadomości ukazywanej przez światło neonowe. ${ }^{22}$ Taką samą tezę głosił węgiersko-brytyjski filozof nauki Michael Polanyi, szczególnie w artykule z 1967 roku zatytułowanym „Life Transcending Physics and Chemistry” [Życie transcenduje fizykę i chemię], jak również w innych publikacjach, począwszy od końca lat 1950-tych. „W latach 1960-tych Michael Polanyi opisał metodę określania przygodności na podstawie stopni wolności. Zastosował ją w celu wykazania, że biologia jest nieredukowalna do fizyki i chemii". ${ }^{23}$ Tuż przed śmiercią Polanyi zainteresował się szczególnie zagadką informacji w DNA i doszedł do przekonania, że

\footnotetext{
${ }^{22}$ Jestem wdzięczny za ten przykład nieżyjącemu już Donaldowi Mackayowi, choć posłużył się nim nieco inaczej. Por. Donald MACKAY, The Clockwork Image, InterVarsity Press, Downers Grove, Ill. 1974.

${ }^{23}$ Dembski, The Design Revolution..., s. 98.
} 
wiedza o prawach fizycznych rządzących budulcem DNA nie wyjaśni adekwatnie pochodzenia samej zakodowanej informacji. ${ }^{24}$

Dembski także rozprawia się z zarzutem „splotu przyczyn”. W The Design Revolution cytuje najpierw zarzut Michaela Ruse'a względem filtra. Ruse opiera się na ideach Ronalda Fishera, jednego z ojców syntezy neodarwinowskiej, która powstała przed rokiem 1950. Według Ruse'a Fisher uważał, że „indywidualne mutacje zachodzą przypadkowo, ale łącznie rządzą nimi prawa (a bez wątpienia są one skutkiem działania praw fizyki i chemii) i dlatego mogą zapewnić materiał dla doboru (prawa), który z nieporządku (przypadku) tworzy porządek”. Ponadto Fisher ,argumentował, że wszystko zaplanował jego anglikański Bóg!" ${ }^{25}$ Ruse twierdzi, że dwie, a może nawet trzy przyczyny są ze sobą nierozerwalnie splątane. A oto odpowiedź Dembskiego:

Ruse myli się twierdząc, że filtr eksplanacyjny rozdziela konieczność, przypadek i projekt na wzajemnie wykluczające się i wyczerpujące kategorie. Filtr jest modelem naszej codziennej praktyki przypisywania tych trybów wyjaśniania. Oczywiście, wszystkie trzy mogą być połączone. Zazwyczaj jednak jeden z trybów wyjaśniania przeważa. Czy zardzewiały, stary samochód na twoim podjeździe został zaprojektowany? Rdza i wgniecenia w karoserii powstały na skutek przypadku i konieczności (warunków pogodowych, grawitacji oraz wielu innych niekierowanych sił naturalnych). Samochód jest jednak również zaprojektowany i właśnie to zazwyczaj jest najbardziej interesujące. Co więcej, skupiając się na odpowiednich aspektach samochodu, filtr wykrywa ten projekt. Ostatecznie, wykrycie projektu przez filtr jest możliwe dzięki wyspecyfikowanej złożoności. Filtr eksplanacyjny to prosta metoda określania wyspecyfikowanej złożoności. Właśnie dlatego jedynym sposobem obalenia filtra eksplanacyjnego jest wykazanie, że wyspecyfikowana złożoność nie jest odpowiednim kryterium wykrywania projektu. ${ }^{26}$

\footnotetext{
${ }^{24}$ Por. Michael Polanyi, „Life Transcending Physics and Chemistry”, Chemical and Engineering News, 21 August 1967.

${ }^{25}$ Dembski, The Design Revolution..., s. 93. Dembski cytuje tutaj, nie podając jednak numeru strony, książkę Michaela Ruse'A, Can a Darwinian Be a Christian? The Relationship between Science and Religion, Cambridge University Press, New York 2001.
} 


\section{Groźba falszywych pozytywów}

Dembski argumentuje, że siłę i skuteczność filtra eksplanacyjnego można ostatecznie ugruntować dzięki wykazaniu, że on się sprawdza. Filtr jest narzędziem solidnym, ponieważ się sprawdza - wielokrotnie, niezawodnie, zawsze, gdy zastosować go do faktów przyrodniczych. Krótko mówiac, nigdy nie odnotowano żadnej jego porażki. Jest to śmiałe stwierdzenie, lecz taki stuprocentowy sukces jest warunkiem wstępnym, aby jakakolwiek teoria mogła stać się niezawodnym narzędziem analitycznym nauki. Pisałem o tej sile filtra już wcześniej, ale zacytujmy samego Dembskiego:

Wykluczając $w$ ten sposób wszystkie mechanizmy materialne, nie twierdzimy, że dane zjawisko jest z natury niemożliwe do wyjaśnienia. Mówimy raczej, że wyjaśniane jest ono nie przez mechanizmy materialne, lecz przez projekt. Whiosek o projekcie nie wyplywa z bujnej wyobraźni, lecz kierowany jest logika indukcji: wtedy, gdy znana jest historia przyczynowa, wyspecyfikowanej złożoności zawsze towarzyszy projekt. Wyspecyfikowana złożoność dostarcza zatem indukcyjnego poparcia nie tylko niemożliwości wyjaśnienia w kategoriach mechanizmów materialnych, ale także możliwości wyjaśnienia w kategoriach projektu. ${ }^{27}$

Innymi słowy, wzorce przyczynowo-skutkowe we Wszechświecie nasuwają jednogłośny werdykt. Nigdy i nigdzie nie odnotowano żadnego przypadku, kiedy w pełni znana historia przyczynowa wyspecyfikowanej złożoności uzyskała jakieś naturalistyczne wyjaśnienie. Jest to ważne z kilku powodów. Po pierwsze, potwierdza zasadność filtra, a jest to przecież procedura formalnie nowa i wymagająca potwierdzenia, aby móc przekonać sceptyków. Uniwersalne poparcie znanych przypadków empirycznych pomaga uzyskać zdecydowaną aprobatę

\footnotetext{
${ }^{26}$ Dembsкi, The Design Revolution..., s. 93 [podkreślenia dodane].

${ }^{27}$ Dembski, The Design Revolution..., s. 99 [podkreślenia dodane].
} 
naukowców. Po drugie, ten indukcyjny fundament pewności co do filtra (opierający się nie na spekulacji, lecz na strukturze przyczynowo-skutkowej Wszechświata) stanowi skuteczną odpowiedź na zarzut typu „Bóg ujawniający się w lukach wiedzy” (God of the Gaps). W myśl tego zarzutu teoretycy projektu niepotrzebnie wprowadzają Boga do małej, tymczasowo niewypełnionej luki, która wtopiona jest w doskonale poznaną tkaninę związków przyczynowo-skutkowych. Zarzutem tym chętnie posługuje się na przykład Neil deGrasse Tyson w pogardliwej krytyce ID, opublikowanej na łamach Natural History. ${ }^{28}$ Tysonowi i innym krytykom stawiającym ten zarzut teoretycy ID odpowiadają, że „Nie chodzi tu o wypełnianie luk. Przeciwnie, wnioskujemy o takim samym rodzaju związku przyczynowo-skutkowego, który podlega indukcyjnej obserwacji tysiące razy dziennie i w całym widzialnym Wszechświecie nie znamy żadnego empirycznego wyjątku od tej reguły".

Właśnie w tym punkcie krytycy ID chcieliby podłożyć swój największy ładunek wybuchowy. Gdyby potrafili zademonstrować jeden, albo lepiej - kilka fałszywych pozytywów, które umknęły filtrowi eksplanacyjnemu, to koncepcja ta stanie się bezużyteczną i nieistotną ciekawostką. Jeżeli znajdziemy fałszywy pozytyw, to filtr nie będzie do niczego przydatny. Musimy jednak najpierw zapytać: czym jest fałszywy pozytyw? A także, czym jest fałszywy negatyw? Rozpatrzmy na początek sprawę fałszywych negatywów.

\section{Falszywe negatywy to nie problem}

Fałszywe negatywy nie stanowią problemu dla filtra, ponieważ darwiniści i teoretycy ID zgodnie je przewidują. Fałszywy negatyw to fałszywa odpowiedź „nie” na kluczowe pytanie: czy to zaprojektowa-

\footnotetext{
${ }^{28}$ Neil deGrasse Tyson, „The Perimeter of Ignorance”, Natural History, November 2005. O Tysonie będzie jeszcze mowa w następnym rozdziale [książki Darwin Strikes Back] jako o ateologicznym wodzireju darwinistów.
} 
no? Inteligencja potrafi naśladować procesy naturalne, a w związku z tym inteligentne działanie niekiedy nie jest wykrywane; przedostaje się przez sieć. Jednym z przykładów mógłby być scenariusz, w którym Ron otrzymał trzy pokery królewskie pod rząd. Każdy obserwator miałby poważne podejrzenia, że za tym zdarzeniem kryje się inteligencja. Załóżmy, zgodnie $\mathrm{z}$ moim podejrzeniem, że rzeczywiście działała tu jakaś inteligencja. Zdarzenie to byłoby zatem zaprojektowane! Jednak nad wyraz powściągliwy filtr Dembskiego i tak by takiego projektu nie wykrył, bowiem szanse matematyczne nastąpienia tego zdarzenia byłyby większe od wszechświatowej granicy prawdopodobieństwa, która wynosi jedną szansę na $10^{150}$. Projekt miał miejsce, ale ze względu na powściągliwą naturę filtra nie został wykryty.

Wyobraźmy sobie tym razem, że gdy Ron otrzymał pierwszego pokera królewskiego, cała czwórka graczy przerwała grę, by to uczcić. Podczas gdy wszyscy przybijali piątki i stukali się szklankami z mrożoną herbatą malinową, Jason potajemnie sprawdził następną (przetasowaną) talię kart. Ku swojemu przerażeniu i podejrzeniom zauważył, że Ron otrzyma drugiego pokera królewskiego. Podejrzewając oszustwo, Jason sprytnie przełożył karty tak, aby Ron otrzymał przeciętne, wyglądające na losowe, rozdanie. Kolejne rozdanie - niby zupełnie zwyczajne - zostało zatem zaprojektowane przez Jasona, ale nikt tego nie zauważył i nigdy nie dałoby się tego wykryć za pomocą filtra. W obu przykładach z pokerem ważny jest fakt, że fałszywe negatywy nie zagrażają filtrowi. One są całkowicie oczekiwane.

\section{Falszywe pozytywy: przypadek \#1}

Zupełnie inną sprawą są fałszywe pozytywy. Fałszywy pozytyw to fałszywa odpowiedź „tak” na pytanie, czy coś zostało zaprojektowane. Jeśli zjawisko $X$ przechodzi przez wszystkie tryby filtra i wykazuje niewiarygodną złożoność (jest niezwykle nieprawdopodobne), a na dodatek jest wysoce wyspecyfikowane, to uznamy je za ,zaprojektowane". A co jeżeli okaże się, że zjawisko X naprawdę nie jest zapro- 
jektowane? Kilku krytyków Dembskiego wskazało takie fałszywe pozytywy i oznajmiło, że koncepcja filtra została obalona. Zdaniem Dembskiego żaden z tych przykładów nie jest fałszywym pozytywem, a $\mathrm{w}$ związku z tym argumenty darwinistów upadają. Kto ma rację?

Omówię dwa domniemane fałszywe pozytywy, które przedstawiono jako przypadki obalające filtr. Pierwszy nazywany jest „ciągiem Fibonacciego" - jest to specjalny ciąg liczbowy, na podstawie którego niektóre rośliny rozmieszczają liście na gałęzi. Darwinista Gert Korthof argumentuje, że codzienne generowanie liczb Fibonacciego w procesie rozmieszczania liści przez pewne gatunki roślin wygląda na zdarzenie zaprojektowane. Jest to zdarzenie równoważne wychwyceniu $\mathrm{z}$ przestrzeni kosmicznej sygnału przedstawiającego ciąg liczb pierwszych. Tylko komputer, korzystając ze wzoru matematycznego, potrafi wygenerować podobny ciąg Fibonacciego. Skoro jednak to złożone i wyspecyfikowane zjawisko nieustannie wydarza się na oczach botanika i nie ingeruje weń żadna inteligencja, to tak jakby przy zastosowaniu filtra Dembskiego uznano, że ciąg Fibonacciego został ,zaprojektowany", podczas gdy w istocie nie jest on wytworem inteligencji.

Dembski ma prostą odpowiedź. Stwierdzenie (jak zrobił to Korthof), że ułożenie liści we wzór Fibonacciego jest wynikiem ,procesu całkowicie naturalnego", to ekwiwokacja związana ze słowem naturalny. Kluczowe pytanie brzmi: jakie zdarzenie uznawane jest za zaprojektowane? Gdzie mamy do czynienia z działaniem inteligencji? Czyżby w codziennym funkcjonowaniu systemu, rozmieszczającego liście zgodnie ze wzorem Fibonacciego, zaprogramowanym w biochemicznej strukturze rośliny? Czy też może chodzi o „proces skonstruowania, czyli uprzednie zaprogramowanie układów biologicznych tak, aby mogły rozmieszczać liście zgodnie ze wzorem Fibonacciego"? Gdybyśmy nawet wspaniałomyślnie przyjęli, że software komórkowy, potrafiący układać liście we wzór Fibonacciego, jest dość prosty i mógł powstać w sposób naturalny, działałby on wyłącznie w ramach bogato rozbudowanego i skomplikowanego hardware'u istniejącej już komórki roślinnej. Dembski stwierdza ponadto, że „,najprostsza funk- 
cjonalna komórka jest zdumiewająco złożona, ma wiele poziomów wyspecyfikowanej złożoności, a zatem jest rezultatem projektu". ${ }^{29}$ Naturalne funkcjonowanie układu mylone jest tutaj z jego powstaniem na mocy projektu. Według Dembskiego to nieporozumienie często występuje w literaturze krytycznej wobec ID.

\section{Falszywe pozytywy: przypadek \#2}

Innym ważnym fałszywym pozytywem, omówionym w kilku książkach (zwłaszcza w tych, w których udział miał Niall Shanks), jest zjawisko znane jako komórki Bénarda. Chodzi o przypominający plaster miodu wzorzec sześciokątnych komórek poruszającej się wody, który powstaje, gdy bardzo cienką warstewkę wody przykrywa się dwiema szklanymi płytkami i podgrzewa od spodu. Typowy tego typu wzorzec tworzy się spontanicznie, a mimo to komórki mogą być nieco odmienne; występuje tutaj duży stopień elastyczności i zmienności, a więc i prawdziwa złożoność, która przekracza ustaloną przez Dembskiego wszechświatową granicę prawdopodobieństwa. Takie cyrkulujące komórki są podobno obserwowane także na powierzchni Słońca. Zdaniem Shanksa największe zagrożenie dla filtra Dembskiego polega na tym, że komórki Bénarda, „które tworzą się za pomocą ślepych mechanizmów naturalnych, zawierają złożoną wyspecyfikowaną informację". Dalej powtarza on twierdzenie, że komórki Bénarda „ukazują CSI, a mimo to powstały na skutek działania naturalnych przyczyn nieinteligentnych". ${ }^{30}$ Ponieważ każda struktura, która naprawdę ukazuje CSI, będzie zapewne zarówno (1) złożona, przechodząc przez dwa pierwsze filtry, oraz (2) wyspecyfikowana, przechodząc przez trzeci i ostatni filtr, konsekwencją tezy Shanksa jest to, że komórki Bénarda uznano tym samym za „zaprojektowane”. Skoro jednak po-

\footnotetext{
${ }^{29}$ Dembsкi, The Design Revolution..., s. 90.

${ }^{30}$ Shanks, God, the Devil, and Darwin..., s. 127, 129 (por. s. 125-129). Por. też YounG and EDIs (eds.), Why Intelligent Design Fails..., s. 91-95.
} 
wstają one w sposób naturalny, a nie za pośrednictwem inteligencji, oznacza to, że filtr doprowadził nas do zwodniczych wniosków.

Najpierw przedstawię swoją osobistą reakcję, następnie zaś pewną opublikowaną wymianę zdań. Przeczytawszy ten rozdział książki Shanksa pomyślałem, że jest to „słaby argument - jakie znaczenie (lub analogię) mają takie komórki wirującej wody dla cyfrowo wyspecyfikowanych sekwencji informacji w DNA czy białkach?" Przypomniałem sobie, co usłyszałem lata temu, gdy pierwsi badacze ID zaczęli formułować argumentację, opartą na wiedzy o informacji. Niektórzy obrońcy teorii ewolucji prebiotycznej wskazywali na wiry mydlanej wody, które spontanicznie tworzą się po wyciągnięciu korka $\mathrm{z}$ wanny. $\mathrm{Ku}$ niezadowoleniu badaczy pochodzenia życia okazało się, że takie wiry faktycznie są uporządkowane, lecz porządek niezbyt wiele ma wspólnego $\mathrm{z}$ informacją. Uporządkowanie czy organizacja w pewnym sensie jest niemalże przeciwieństwem informacji, bowiem uporządkowanie występuje tylko w prostych, czy też regularnych lub periodycznych strukturach, takich jak kryształ soli. Z drugiej strony, informacja w komórce ma zgoła odmienny charakter, gdyż jest wyraźnie aperiodyczna, tzn. nie składa się z prostych i powtarzających się wzorców. Przeczytawszy zatem o komórkach Bénarda pomyślałem: „Znowu wiry mydlanej wody, tyle że tym razem nie chodzi o mydło, lecz o wodę umieszczoną pomiędzy szklanymi płytkami!"

Komórki te pozbawione są prawdziwych oznak złożonej informacji. Co więcej, z pewnością nie są „niezależnie wyspecyfikowane” dla jakiejś docelowej funkcji. Nie można zaklasyfikować ich jako CSI. Filtr wyłapuje je na pierwszym lub drugim poziomie: można je wyjaśnić jako proste wzorce, kierowane procesami prawopodobnymi (przy właściwych warunkach początkowych zawsze tworzą ten sam podstawowy wzorzec), choć występują w nich różne niewielkie odchylenia, związane z powodowaną przez działanie przypadku zmiennością zewnętrznego środowiska. Wygląda na to, że nie przechodzą one do ostatniego filtra. Być może jednak Shanks chciałby zejść na poziom molekularny, na którym biliony cząsteczek wody wirują w unikatowy sposób. Mógłby wtedy wykazać, że zbiorowe ruchy tych cząsteczek są 
tak złożone, iż nieprawdopodobieństwo tworzonego przez nie wzorca przekracza granicę ustaloną przez Dembskiego. Odpowiedziałbym: „W porządku. Zejdźmy na poziom molekularny. Jak tylko to zrobimy, wspaniałe komórki Bénarda natychmiast trafią do analitycznego kubła na śmieci z napisem przypadek, ponieważ nie przejdą testu na specyfikację". Innymi słowy, nie mogą one przejść przez ostatni filtr, a tym samym nie ma podstaw, by nadać im miano CSI.

Cornellius Hunter, biofizyk, który zrecenzował książkę Why Intelligent Design Fails, skomentował przykład komórek Bénarda następująco: „Zarzut ten nie wydaje się jednak obalać ID. Niall Shanks i Istvan Karsai argumentują, że złożoność może powstawać za pomocą mechanizmów całkowicie lokalnych. Jednak (...) wytworzenie komórek Bénarda (...) wymaga pomysłowego przyrządu”. ${ }^{31}$ Można innymi słowy zapytać, co będąca środowiskiem sztucznym, precyzyjnie zbudowana struktura laboratoryjna, utworzona z dwóch szklanych płytek, całkowicie wypełnionej wodą, cieniutkiej szczeliny oraz starannie modulowanego, równomiernie dostarczanego źródła ciepła, ma wspólnego z brutalnymi środowiskami naturalnymi, w których materia kształtowana jest na wszelkie możliwe sposoby? Czy nie jest możliwe, że to widoczne w wirach niewielkie (nie niosące informacji) uporządkowanie jest przewidywalnym skutkiem precyzyjnie określonych przez eksperymentatorów, inteligentnie (tj. nienaturalnie) dobranych warunków? Zgadzam się z Hunterem, że omawiane przykłady nie mają istotnego wpływu na zagadnienia CSI i filtra eksplanacyjnego. Dogłębna analiza obala oba rzekome ,fałszywe pozytywy”. Ponownie wykazaliśmy słuszność filtra.

\footnotetext{
${ }^{31}$ Cornelius Hunter, „Can Science Refute Design? A Book Review of Why Intelligent Design Fails”, Origins, 21 June 2005, no. 58, s. 37.
} 


\section{Konkluzja}

Opuszczając spowite dymem pole walki toczonej o idee Williama Dembskiego, warto zarysować ogólniejszy obraz tego, co z dyskusji nad CSI i filtrem dowiedzieliśmy się o Wszechświecie. Jeden z najważniejszych rozdziałów The Design Revolution (a jest ich wiele) ${ }^{32}$ zatytułowany jest „Information Ex Nihilo” [Informacja z niczego]. Na początku rozdziału Dembski umieścił epigraf: „Czy przyroda jest kompletna $\mathrm{w}$ sensie posiadania wszystkich zdolności potrzebnych do tworzenia bogatych $\mathrm{w}$ informację struktur obserwowanych w świecie, zwłaszcza $\mathrm{w}$ biologii? Czy też może pewne informacyjne aspekty świata nie mogły zaistnieć $\mathrm{w}$ wyniku działania samej przyrody, lecz wymagały kierownictwa inteligencji?" Odpowiadając na te pytania, Dembski cofa się w wyobraźni do ognistej, hiperskompresowanej zbitki kwarków, która pojawiła się tuż po nastąpieniu wielkiego wybuchu, i pyta, czy „wszystkie możliwe złożone formy życia, jak my, istniały już w pewnym sensie w tym odległym momencie czasu". Wielu ludzi zakłada odpowiedź twierdzącą, ale ta wczesna historia Wszechświata „i tak nie rozstrzyga, skąd się tu wzięliśmy, albo czy przyroda miała wystarczającą moc stwórczą, aby wytworzyć nas bez pomocy projektu". ${ }^{33}$ Holmes Rolston, wybitny filozof środowiska, pracujący w Colorado State University, oraz laureat Nagrody Templetona, w książce Genes, Genesis and God [Geny, Księga Rodzaju i Bóg] twierdzi, że w żadnym sensie istoty ludzkie lub jakiekolwiek inne stworzenia nie są utajone $\mathrm{w}$ organizmach jednokomórkowych. Jego zdaniem twierdzenie, że życie drzemie w związkach chemicznych lub

\footnotetext{
${ }^{32}$ Dembsкi, The Design Revolution.... Za szczególnie polemiczne z darwinizmem uważam następujące rozdziały: rozdz. 19, „Information Ex Nihilo”; rozdz. 25-26, „The Supernatural” oraz „Embodied and Unembodied Designers”; rozdz. 30, „The Argument from Ignorance”, oraz rozdz. 36, „The Only Game in Town”.

${ }^{33}$ Dembsкi, The Design Revolution..., s. 145.
} 
że złożone formy życia kryją się w prostych układach biologicznych, jest ,aktem wiary”. ${ }^{34}$

Dembski mówi jednak, że życie wyłoniło się z ,jałowego, wrzącego i niespokojnego kotła" pradawnej Ziemi. Jak to się stało? Jaka była tego przyczyna? Dembski pisze: „Możemy snuć domysły, że odpowiadają za to jedynie ślepe siły przyrody. Ale jak możemy dowiedzieć się, czy to prawda? Zgodnie $\mathrm{z}$ teorią inteligentnego projektu wyspecyfikowana złożoność organizmów żywych niezbicie dowodzi, że ślepe siły przyrody nie mogły wytworzyć ich same, lecz ich powstanie wymagało udziału projektującej inteligencji”. ${ }^{35} \mathrm{~W}$ tym punkcie Dembski mógłby powiedzieć coś nowego na stary temat - stworzenia z niczego. Jednak nie interesuje go tutaj kwestia powstania Wszechświata z niczego. Próbuje on raczej zbadać źródło informacji, aby sprawdzić, czy ona powstała w ten sposób:

Istnienie projektu w przyrodzie wskazuje zatem, że jest ona niekompletna. Innymi słowy, przyroda zawiera projekt, którego sama nie potrafi wytworzyć. Co więcej, skoro projekt w przyrodzie rozpoznajemy za pomocą wyspecyfikowanej złożoności i skoro wyspecyfikowana złożoność jest formą informacji, przekraczającą zdolności stwórcze przyrody, to wynika z tego, że wyspecyfikowana złożoność oraz ukazywany przez nią projekt stanowią informację powstałą z niczego. Czyli jest to informacja, której nie można wywieść z oddziaływania sił przyrody na istniejący już materiał. Przypisywanie wyspecyfikowanej złożoności układów biologicznych siłom przyrody jest jak stwierdzenie, że litery do gry w Scrabble potrafią samodzielnie układać się w sensowne wyrażenia. Obydwa twierdzenia są równie absurdalne, ale w biologii ewolucyjnej absurdy powtarzane są tak często, że już ich nie dostrzegamy.

\footnotetext{
${ }^{34}$ Holmes Rolston III, Genes, Genesis and God: Values and Their Origins in Natural and Human History, Cambridge University Press, New York 1999 (cyt. za: Dembski, The Design Revolution..., s. 146).

${ }^{35}$ Wszystkie cytaty oraz informacje w tym i pozostałych akapitach tego rozdziału pochodzą z Dembski, The Design Revolution..., s. 146-148.
} 
Dembski nie rozumie wyrażenia ,z niczego" jako ,z niczego $\mathrm{w}$ sensie absolutnym”, a raczej jako „z niczego w samej przyrodzie”. W pozostałej części omawianego rozdziału Dembski, na przekór Niallowi Shanksowi, argumentuje (i zgadzam się z nim), że należy przeciwstawiać nie przyczyny naturalne przyczynom ,nadnaturalnym i cudownym", lecz przyczyny naturalne przyczynom inteligentnym. Wykonując działania jako ludzie, robiąc rzeczy, których przyroda nigdy nie mogłaby zrobić, nie łamiemy praw przyrody; działamy po prostu jako istoty inteligentne, każdego dnia dokonując wyborów i tworząc małe szczyty wyspecyfikowanej złożoności. W procesie tym nie łamiemy zatem praw przyrody. Niemniej, nawet chociaż inteligentny projekt nie implikuje sprzeczności z nimi, ,ukazuje zasadnicze ograniczenie praw przyrody, a mianowicie to, że są one niekompletne".

Wynikiem analizy Dembskiego jest prowokacyjny wniosek: „Teoria inteligentnego projektu uznaje inteligencję za nieredukowalną cechę rzeczywistości. W rezultacie każdą próbę podciągnięcia aktywności inteligentnej pod przyczyny naturalne postrzega jako z gruntu chybioną, a prawa przyrody, opisujące przyczyny naturalne, traktuje jako zasadniczo niekompletne".

W pewnym sensie badania naukowe nad CSI i filtrem eksplanacyjnym to obecnie nadzwyczaj niebezpieczna dziedzina nauki - niebezpieczna dla długoletnich tradycji, dotyczących sposobu badania wszystkich poziomów świata. Jest taka, ponieważ grozi przekształceniem i reorganizacją długo ustanawianej hierarchii między naukami przyrodniczymi a naukami badającymi inne (lub ogólniejsze) sfery rzeczywistości, wliczając $\mathrm{w}$ to metodologię nauki, filozofię, a nawet teologię. 